\title{
Modeling and kinetic study of bio-ethanol production from soy protein concentrate by-product
}

\author{
Lucas CALDEIRÃO ${ }^{1 *}$, Cyntia TANAKA ${ }^{1}$, Elza IDA ${ }^{1}$, Wilma SPINOSA ${ }^{1}$
}

\begin{abstract}
The aim of this work was to evaluate a non-agitated process of bioethanol production from soybean molasses and the kinetic parameters of fermentation using a strain of Saccharomyces cerevisiae (ATCC ${ }^{\circledR}$ 2345). Kinetic experiment was conducted in medium with $30 \%\left(\mathrm{w} \mathrm{v}^{-1}\right)$ of soluble solids without supplementation or $\mathrm{pH}$ adjustment. The maximum ethanol concentration was in 44 hours, the ethanol productivity was $0.946 \mathrm{~g} \mathrm{~L}^{-1} \mathrm{~h}^{-1}$, the yield over total initial sugars $\left(\mathrm{Y}_{1}\right)$ was $47.87 \%$, over consumed sugars $\left(\mathrm{Y}_{2}\right)$ was $88.08 \%$ and specific cells production rate was $0.006 \mathrm{~h}^{-1}$. The mathematical polynomial was adjusted to the experimental data and provided very similar parameters of yield and productivity. Based in this study, for one ton of soybean molasses can be produced $103 \mathrm{~kg}$ of anhydrous bioethanol.
\end{abstract}

Keywords: alcoholic fermentation; bioethanol; soybean molasses; co-product valorization.

Practical Application: Static fermentation showed high yield to ethanol production from soybean molasses.

\section{Introduction}

Bioethanol is a viable alternative to petroleum-based fuels, since fossil fuels are limited and generate greater environmental impact. Bioethanol has low production costs, easy of operation and can be obtained from different raw materials materials (Cardona \& Sánchez, 2007; Balat et al., 2008; Sage et al., 2009; Nikolic et al., 2010). Any sugar or starch raw material can be converted to ethanol by microorganisms. The substrate should allow growth of the microorganism without interfering with product recovery. The substrate must be economically viable and available in quantity for the industrialization of the fermentation process (Srichuwong et al., 2009; Oda \& Nakamura, 2009; Behera et al., 2010).

In Brazil, after 1975, a program was implemented to encourage the use of sugarcane bioethanol to replace gasoline in addition to encouraging the mixture of ethanol and gasoline used in common cars. This measure increased production and consumption of ethanol in the country, and promoted research for various raw materials to obtain ethanol, in addition of sugar cane as well as the production of second generation ethanol (Gámez et al., 2005; Miller et al., 2012).

Soy is one of the crop most widely produced in Brazil and in the world due to its versatility in cultivation and processing, generating various products and co-products used by the food, animal feed and agrochemical industries (Silva et al., 2012). The soy molasses is a viscous liquid of brown color and sweet-sour taste obtained from the processing of the soy protein industry concentrate ( $70 \%$ dry basis). The defatted soy flour is washed with ethanol and water to the proteins concentration, so, the carbohydrates and other soluble compounds are drawn and subsequently concentrated by evaporation of the ethanol and part of the water, resulting in the molasses. The main components of the molasses sugars are sucrose, raffinose and stachyose (Siqueira et al., 2008). The soybean molasses contains proteins, lipids, minerals and isoflavones in addition to carbohydrates (Hosny \& Rosazza, 1999; Siqueira et al., 2008). Much of this co-product is used for animal feed or else discarded as waste. In Brazil already exist soybean processing industries that use the soy molasses for production of hydrated alcohol, however, the use of this ethanol is limited as an alternative energy for these industries (Machado, 1999; Siqueira et al., 2008, Romão et al., 2012). Besides fuel, the soybean molasses ethanol can be used as raw material for the food industry or even the development of a distilled beverages.

Industries conduce alcoholic fermentations without agitation due the lack of equipment and its high cost, so this study aimed to evaluate the static process of ethanol production from soy molasses and their kinetic parameters applying a mathematical modelling.

\section{Materials and methods}

\subsection{Raw material}

The soybean molasses ( $74.5 \%$ soluble solids) was donated by the Selecta ${ }^{\circledR}$ soybean factory, located in Araguarí, Minas Gerais (Brazil). The samples were storaged in plastic containers $(5 \mathrm{~kg})$ at $4{ }^{\circ} \mathrm{C}$ until they are ready to use.

\subsection{Characterization of the soybean molasses}

Dry extract and ashes were determined by gravimetric method after drying at $105{ }^{\circ} \mathrm{C}$ and calcination at $550{ }^{\circ} \mathrm{C}$, respectively, until constant weight; proteins were determined by 
Kjeldahl method (Association of Official Analytical Chemists, 2005). Lipids were determined by Bligh-Dyer method (Bligh \& Dyer 1959). Total sugars were determined by phenol-sulfuric acid method (DuBois et al., 1956). The results are presented as average of three analyses.

\subsection{Activation and inoculum preparation}

Lyophilized Saccharomyces cerevisiae strain (ATCC $\left.{ }^{\circledR} 2345\right)$, obtained from tropical Research Foundation "André Tosello" culture collection, was activated in sterile yeast, malt broth (YM) (Himedia ${ }^{\circledR}$ ) and incubated in a shaker (Cientec ${ }^{\circledR}$, Brazil, CT-712 R) at $30{ }^{\circ} \mathrm{C}$ and agitated at $150 \mathrm{rpm}$ for $24 \mathrm{~h}$. After activation, $10 \%\left(\mathrm{v} \mathrm{v}^{-1}\right)$ of this broth was transferred to aqueous soybean molasses $10^{\circ}$ Brix sterile $\left(15\right.$ minutes at $121^{\circ} \mathrm{C}$; $\mathrm{FABBE}^{\circledR}$, Brazil, Primar) and incubated in the same conditions of temperature and agitation of the activation step. After $24 \mathrm{~h} 10 \%\left(\mathrm{v} \mathrm{v}^{-1}\right)$ of this inoculum was transferred to sterile molasses diluted to $20^{\circ} \mathrm{Brix}$ and incubated for $24 \mathrm{~h}$ at $30^{\circ} \mathrm{C}$. This last media was used as inoculum to conduction of the assays.

\subsection{Effect of initial concentration of soybean molasses}

The ethanol yield over total initial sugars $\left(\mathrm{Y}_{1}\right)$, yield over consumed sugars $\left(\mathrm{Y}_{2}\right)$ and productivity were evaluated from three initial soybean molasses concentrations (20, 25 and $30^{\circ}$ Brix). The fermentations were conducted in Erlenmeyer flasks and incubated (TECNAL ${ }^{\circledR}$, Brazil, B.O.D. TE-391) at $30^{\circ} \mathrm{C}$ with $10 \%$ $\left(\mathrm{v} \mathrm{v}^{-1}\right)$ of inoculum $\left(10^{7}\right.$ initial cells $\left.\mathrm{ml}^{-1}\right)$ at a $\mathrm{pH}$ value of 5.5.
The fermentation was conducted until there was no liberation of $\mathrm{CO}_{2}$ (visual analysis). Each assay was realized in duplicate.

\subsection{Modeling, kinetic parameters and yield of fermentation}

As showed the results of effect of initial concentration of soybean molasses over fermentation, the best condition $\left(30^{\circ} \mathrm{Brix}, 10 \%\left(\mathrm{v} \mathrm{v}^{-1}\right)\right.$ initial inoculum, $\mathrm{pH}$ of 5.5 and $\left.30^{\circ} \mathrm{C}\right)$ was used to obtain the kinetic parameters. The essay was conducted in a bioreactor (Biofoco ${ }^{\circledR}$, Brazil. Rubia basic). It was collected samples for counting cells, total sugars and ethanol content determinations until $140 \mathrm{~h}$ of fermentation.

Parameter of ethanol yields over total initial sugars $\left(\mathrm{Y}_{1}\right)$ (Equation 1), total consumed sugars $\left(\mathrm{Y}_{2}\right)$ (Eqquation 2), total sugars in ethanol conversion $\left(\mathrm{Y}_{\mathrm{p} / \mathrm{s}}\right.$ (Equation 3), ethanol productivity (Equation 4) and specific growth rate ( $\mu \mathrm{x})$ (Equation 8 ) were determined in maximum ethanol concentration. The parameters of growth rate $(\mathrm{rx})$ total sugars consumption rate $(\mathrm{rs})$ (and ethanol production rate (rp) were determined from inclination (angle) of linear equation obtained from kinetic of cells and bioethanol formation and total sugars consumption data (Figure 1) represented by the Equations 5, 6 and 7, respectively. The cell generation time ( $\mathrm{tg}$ ) was determined by division of the time of maximum number of cells by the number of yeast cell generations (n) (Equations 9 and 10). A polynomial equation of third order was adjusted to experimental data, representing cells, total sugars and ethanol concentrations as time dependent functions.
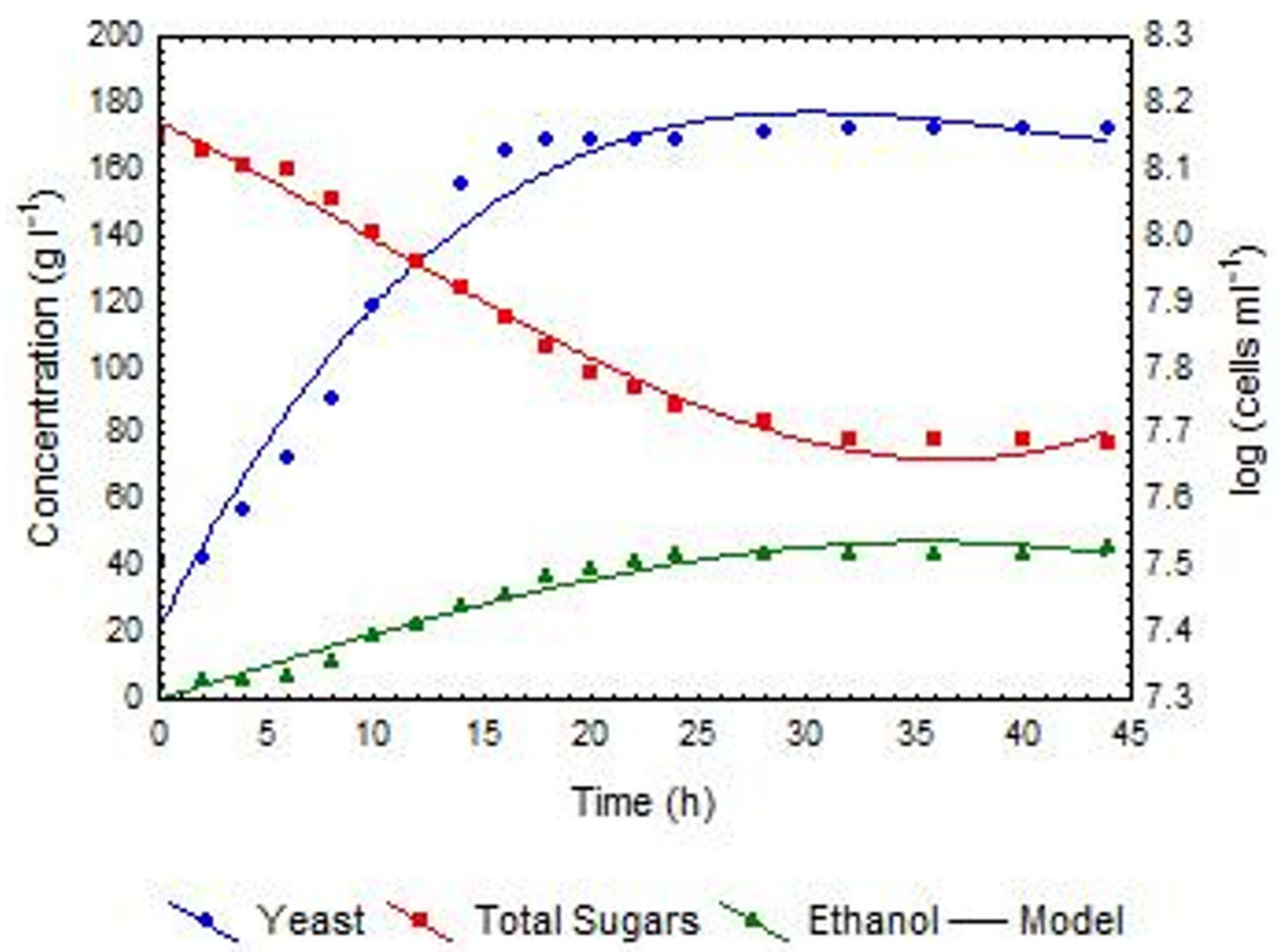

Figure 1. Evolution of ethanol concentration, total sugars and yeast cells as a function of the fermentation time from practical and theoretical data. 


$$
\begin{aligned}
& Y_{1}(\%)=\frac{\left(E t_{f}-E t_{i}\right) * 100}{\left(T S_{i}\right) * 0.511} \\
& Y_{2}(\%)=\frac{\left(E t_{f}-E t_{i}\right) * 100}{\left(T S_{i}-T S_{f}\right) * 0.511} \\
& Y_{P / S}(\%)=\frac{\left(E t_{f}-E t_{i}\right) * 100}{\left(T S_{i}-T S_{f}\right)} \\
& \operatorname{Productivity}\left(g L h^{-1}\right)=\frac{E t_{f}}{t_{f}} \\
& r x\left(\log c e l m L^{-1} h^{-1}\right)=\frac{X_{f}-X_{i}}{t_{f}-t_{i}} \\
& \operatorname{tg}(h)=\frac{t_{t}}{n} \\
& n=\frac{X L_{f}-X_{i}}{\log 2} \\
& \left.\operatorname{ri}(h)=r x * \frac{1}{X} h^{-1}\right)=\frac{T S_{i}-T S_{f}}{t_{f}-t_{i}} \\
& \left.r L^{-1} h^{-1}\right)=\frac{E t_{f}-E t_{i}}{t_{f}-t_{i}}
\end{aligned}
$$

Where, $\mathrm{Et}_{\mathrm{f}}$ is the final ethanol content $\left(\mathrm{g} \mathrm{L}^{-1}\right)$; $\mathrm{Et}_{\mathrm{i}}$ is the initial ethanol content $\left(\mathrm{g} \mathrm{L}^{-1}\right)$; $\mathrm{TS}_{\mathrm{i}}$ is the final total sugar content $\left(\mathrm{g} \mathrm{L}^{-1}\right)$; $\mathrm{TS}_{\mathrm{f}}$ is the final total sugar content $\left(\mathrm{g} \mathrm{L}^{-1}\right) ; 0.511$ is the maximum theoretical conversion (stoichiometric) of hexose to ethanol; $\mathrm{t}$ is time $(\mathrm{h}) ; \mathrm{X}_{\mathrm{f}}$ is the final cell concentration (log cells $\mathrm{mL}^{-1}$ ); $\mathrm{X}_{\mathrm{i}}$ is the initial cell concentration ( $\log$ cells $\mathrm{mL}^{-1}$ ); $\mathrm{t}_{\mathrm{f}}$ is the final fermentation time $(h) ; t_{i}$ is the initial fermentation time $(h)$; $t_{t}$ is the time at the maximum counting cell value $(h) ; n$ is the number of cell generations.

\subsection{Determinations of total sugars, ethanol and cells count}

Total sugars were determined by phenol-sulfuric acid reaction, using glucose as standard. The analysis consists in addiction of $2.5 \mathrm{~mL}$ of sulfuric acid and $0.5 \mathrm{~mL} 5 \%\left(\mathrm{w} \mathrm{v}^{-1}\right)$ phenol solution over $0.5 \mathrm{~mL}$ of diluted sample and keep the reaction at room temperature for 20 minutes. After the reaction time, the optical density is determined at $480 \mathrm{~nm}$ in spectrophotometer (DuBois et al., 1956).

Alcoholic fermented samples were previously distilled in micro-distiller of alcohol (TECNAL ${ }^{\circledR}$, Brazil, TE-012) and alcohol concentration was determined by digital densitometry (Rudolph Research Analytical $^{\circledR}$, EUA, DDM 2909) (Spinosa et al., 2015).

Cell concentration was quantified in Neubauer counting. The viable cells were differentiated by the methylene-blue staining method $\left(1 \% \mathrm{w} \mathrm{v}^{-1}\right)$ and the concentration expressed as the logarithm of cells per $\mathrm{mL}$ (log cells $\mathrm{ml}^{-1}$ ) (Silva et al., 2012).

\subsection{Statistical analysis}

When required, Tukey test $(\mathrm{p}=0.05)$ was used to determine statistical differences between means. The polynomial regression was obtained from Statistica 7.0 (Statsoft, 2004).

\section{Results and discussion}

\subsection{Characterization of soybean molasses}

Table 1 shows the main components in soybean molasses.

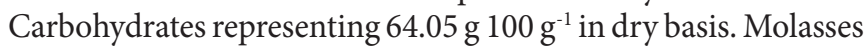

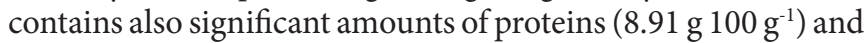

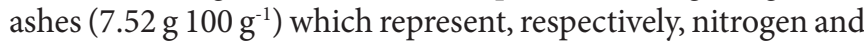
minerals sources, these components are important for yeast cell growth (Nahvi et al., 2002; Siqueira et al., 2008).

\subsection{Effect of initial concentration of soybean molasses}

The fermentation time (Table 2) increased proportionally to the initial total sugar concentration. Despite the increase of the fermentation time, the ethanol productivity was not affected by elevation of initial concentration of molasses, it kept statistically equal for the three assays. It is possible to observe that initial concentration of soybean molasses does not influenced in ethanol yield over total sugar $\left(\mathrm{Y}_{1}\right)$, however, the ethanol yield over consumed sugar $\left(\mathrm{Y}_{2}\right)$ was higher in $30^{\circ}$ Brix initial concentration than in 20 and $25^{\circ} \mathrm{Brix}$. The experiments conducted in 20 and $25^{\circ}$ Brix were not significantly different. The ethanol concentration increased with increasing of initial concentration of molasses, this occurred due the higher concentration of available total sugar to be converted. Remaining sugars are the non-fermentable fractions of total sugar, raffinose and stachyose. This carbohydrates present $\alpha-1,6$ bounds, which are not broken by S. cerevisiae enzymes (Lan et al., 2007).

In a similar study, Siqueira et al. (2008) using agitation, observed a yield $\left(\mathrm{Y}_{1}\right)$ of $40.97 \%$ and $56 \mathrm{~g} \mathrm{~L}^{-1}$ of final ethanol concentration, starting from $30^{\circ}$ Brix soybean molasses, after 30 hours of fermentation.

The assay with $30{ }^{\circ}$ Brix initial concentration was chosen for the kinetic studies due its higher yield $\left(\mathrm{Y}_{2}\right)$ and ethanol production, when compared to the other assays.

\subsection{Modeling, kinetic parameters and yield of fermentation}

The fermentation time was 44 hours (Table 3 ), after this, the ethanol concentration was maximum and constant. From the experimental data it was proposed a third order polynomial mathematical model (Equations 11, 12 and 13), in which, it was used to determine the theoretical data of yeast cell concentration, total sugars and ethanol content.

Table 1. Composition of soybean molasses in dry basis.

\begin{tabular}{lc}
\hline \multicolumn{1}{c}{ Component } & g $\mathbf{1 0 0} \mathbf{~ g}^{-1}$ \\
\hline Ashes & $7.52 \pm 0.05$ \\
Lipids & $9.46 \pm 0.26$ \\
Proteins & $8.91 \pm 0.08$ \\
Total sugars & $64.05 \pm 0.24$ \\
Total dry extract & $72.61 \pm 0.27$ \\
\hline
\end{tabular}


Table 2. Effect of soybean molasses concentration (Brix) on ethanol yield and productivity*.

\begin{tabular}{|c|c|c|c|c|c|c|c|}
\hline Brix & $\begin{array}{c}\text { Time } \\
(\text { h) }\end{array}$ & $\begin{array}{c}\mathrm{TS}_{\mathrm{i}} \\
\left(\mathrm{g} \mathrm{L}^{-1}\right)\end{array}$ & $\begin{array}{c}\mathrm{TS}_{\mathrm{f}} \\
\left(\mathrm{g} \mathrm{L}^{-1}\right)\end{array}$ & $\begin{array}{c}\mathrm{Et} \\
\left(\mathrm{g} \mathrm{L}^{-1}\right)\end{array}$ & $\begin{array}{l}Y_{1} \\
(\%)\end{array}$ & $\begin{array}{l}\mathrm{Y}_{2} \\
(\%) \\
\end{array}$ & $\begin{array}{c}\text { Productivity } \\
\left(\mathrm{g} \mathrm{L}^{-1} \mathbf{h}^{-1}\right)\end{array}$ \\
\hline 20 & 48 & 123.38 & 56.52 & 22.75 & $35.64 \pm 0.63^{a}$ & $65.10 \pm 2.12^{\mathrm{b}}$ & $0.474 \pm 0.00^{\mathrm{a}}$ \\
\hline 25 & 72 & 143.72 & 52.81 & 32.53 & $43.09 \pm 1.63^{\mathrm{a}}$ & $68.65 \pm 1.92^{\mathrm{b}}$ & $0.439 \pm 0.01^{\mathrm{a}}$ \\
\hline \multirow{2}{*}{30} & 96 & 190.23 & 95.28 & 40.79 & \multirow{2}{*}{$39.51 \pm 3.46^{\mathrm{a}}$} & \multirow{2}{*}{$86.03 \pm 2.79^{a}$} & \multirow{2}{*}{$0.401 \pm 0.03^{\mathrm{a}}$} \\
\hline & 96 & 191.36 & 110.78 & 36.24 & & & \\
\hline
\end{tabular}

${ }^{\star} \mathrm{TS}_{\mathrm{i}}$, total initial sugars; $\mathrm{TS}_{\mathrm{p}}$ total final sugars; Et, ethanol concentration; $\mathrm{Y}_{1}$, yield over total initial sugars, $\mathrm{Y}_{2}$, yield over consumed sugars. Means followed by different letters on the same line indicates significant difference $(\mathrm{p}<0.05)$.

Table 3. Experimental data obtained from kinetic study and theoretical data determined from mathematical models ${ }^{\star}$.

\begin{tabular}{|c|c|c|c|c|c|c|}
\hline \multirow{2}{*}{$\begin{array}{c}\text { Time } \\
\text { (h) }\end{array}$} & \multicolumn{3}{|c|}{ Experimental data } & \multicolumn{3}{|c|}{ Theoretical data } \\
\hline & $\begin{array}{c}\log \\
\left(\text { cells } \mathbf{m L}^{-1}\right)\end{array}$ & $\begin{array}{c}\text { TS } \\
\left(\mathrm{g} \mathrm{L}^{-1}\right)\end{array}$ & $\begin{array}{c}\mathrm{Et} \\
\left(\mathrm{g} \mathrm{L}^{-1}\right)\end{array}$ & $\begin{array}{c}\log \\
\left(\text { cells } \mathbf{m L}^{-1}\right) \\
\end{array}$ & $\begin{array}{c}\text { TS } \\
\left(\mathrm{g} \mathrm{L}^{-1}\right)\end{array}$ & $\begin{array}{c}\mathrm{Et} \\
\left(\mathrm{g} \mathrm{L}^{-1}\right)\end{array}$ \\
\hline $\mathbf{0}$ & 7.51 & 170.20 & 4.74 & 7.41 & 174.31 & 0.00 \\
\hline 2 & 7.51 & 165.62 & 5.21 & 7.53 & 167.65 & 4.06 \\
\hline 4 & 7.59 & 161.15 & 6.16 & 7.64 & 160.66 & 8.13 \\
\hline 6 & 7.66 & 159.55 & 7.27 & 7.74 & 153.42 & 12.13 \\
\hline 8 & 7.75 & 150.67 & 11.14 & 7.82 & 146.01 & 16.02 \\
\hline 10 & 7.89 & 140.66 & 18.88 & 7.90 & 138.52 & 19.79 \\
\hline 12 & 7.96 & 131.77 & 22.67 & 7.96 & 131.02 & 23.40 \\
\hline 14 & 8.08 & 123.93 & 27.73 & 8.02 & 123.59 & 26.84 \\
\hline 16 & 8.13 & 115.30 & 31.05 & 8.06 & 116.32 & 30.08 \\
\hline 18 & 8.14 & 105.97 & 37.13 & 8.10 & 109.29 & 33.10 \\
\hline 20 & 8.14 & 98.95 & 39.58 & 8.13 & 102.59 & 35.87 \\
\hline 22 & 8.15 & 93.40 & 41.63 & 8.16 & 96.28 & 38.36 \\
\hline 24 & 8.15 & 88.01 & 43.13 & 8.17 & 90.46 & 40.57 \\
\hline 28 & 8.15 & 83.33 & 43.14 & 8.19 & 80.60 & 43.99 \\
\hline 32 & 8.16 & 78.48 & 43.21 & 8.20 & 73.65 & 45.95 \\
\hline 36 & 8.16 & 78.24 & 43.61 & 8.19 & 70.27 & 46.24 \\
\hline 40 & 8.16 & 77.95 & 43.87 & 8.18 & 71.11 & 44.68 \\
\hline 44 & 8.16 & 77.71 & 46.37 & 8.17 & 76.82 & 41.08 \\
\hline
\end{tabular}

${ }^{*} \mathrm{TS}$, total sugars; Et, ethanol concentration.

Comparing the theoretical and experimental data, it was possible to observe that, for practical cell concentration, the maximum value was $8.16 \log$ cells $\mathrm{mL}^{-1}$ after 32 hours of fermentation, while the model presented $8.20 \log$ cells $\mathrm{mL}^{-1}$ at the same time. For the final time, the theoretical data presented 8.17 log cells $\mathrm{mL}^{-1}$ versus $8.16 \log$ cells $\mathrm{mL}^{-1}$ of experimental data. The values determined by sugars consumption equation was very similar to the experimental, however, the model proposes the minimum total sugar concentration after 36 hours of fermentation, whilst practical data showed the minimum after 44 hours (Figure 1).

$$
\begin{aligned}
& \text { Yeast }\left(\log \text { cells } \mathrm{ml}^{-1}\right)=7.4078+0.0645 \mathrm{t}-0.0017 \mathrm{t}^{2}+1.42 \mathrm{E}^{-5} \mathrm{t}^{3} \\
& \text { Total Sugars }\left(\mathrm{g} l^{-1}\right)=174.3064-3.232 \mathrm{t}-0.0517 \mathrm{t}^{2}+0.0017 \mathrm{t}^{3} \\
& \text { Ethanol }\left(\mathrm{g} \mathrm{l}^{-1}\right)=0.00+2.074 \mathrm{t}-0.0039 \mathrm{t}^{2}-0.0005 \mathrm{t}^{3}
\end{aligned}
$$

Regarding the ethanol concentration, the maximum experimental value was $46.47 \mathrm{~g} \mathrm{~L}^{-1}$ after 44 hours, at this time, the mathematical model showed $41.08 \mathrm{~g} \mathrm{~L}^{-1}$, but the real produced ethanol $\left(\mathrm{Et}_{\mathrm{f}}-\mathrm{Et}_{\mathrm{i}}\right)$ was $41.63 \mathrm{~g} \mathrm{~L}^{-1}$, very close of the predicted value. The maximum ethanol concentration determined from the model was $46.24 \mathrm{~g} \mathrm{~L}^{-1}$ after 36 hours of fermentation, what did not occur.

For 44 hours of fermentation (Table 4), it was observed the maximum consumption of total sugars and production of ethanol. Consumption of total sugars (dTS) and ethanol production (dEt) were, respectively, $92.49 \mathrm{~g} \mathrm{~L}^{-1}$ and $41.63 \mathrm{~g} \mathrm{~L}^{-1}$. The yield from sugar $\left(\mathrm{Y}_{\mathrm{p} / \mathrm{s}}\right)$ was $45.01 \%$, this value represents $80.08 \%$ of maximum theoretical $\left(\mathrm{Y}_{2}\right)$. The yield over total initial sugars $\left(\mathrm{Y}_{1}\right)$ indicates the amount of ethanol was generated from total initial sugar in the fermentative process, the apparent low value $(45.01 \%)$ in this study is related the amount of fermentative sugars in soybean molasses. Remaining sugars represents, mainly, the amount of stachyose and raffinose, non-fermentable by S. cerevisiae as it is showed by other industries (Machado, 1999; Siqueira et al., 2008, Romão et al., 2012). However, the low cost of soybean molasses and high fermentable sugar to ethanol conversion $(88.08 \%)$ are indicatives that this study is relevant. 
The mathematical model indicated $97.49 \mathrm{~g} \mathrm{~L}^{-1}$ for sugars consumption and $41.08 \mathrm{~g} \mathrm{~L}^{-1}$ for ethanol production, which represented the yield $\left(\mathrm{Y}_{\mathrm{p} / \mathrm{s}}\right)$ of $42.14 \%$ and $82.46 \%$ for yield over consumed sugars $\left(\mathrm{Y}_{2}\right)$. The yield over total initial sugars $\left(\mathrm{Y}_{1}\right)$ proposed by the model was $46.12 \%$. The practical and theoretical productivity was $0.946 \mathrm{~g} \mathrm{~L}^{-1} \mathrm{~h}^{-1}$ and $0.934 \mathrm{~g} \mathrm{~L}^{-1} \mathrm{~h}^{-1}$, respectively.

The similarity of yields and productivity indicates that the models are well-adjusted to the experimental data, generating values closed to the practical, and can be used for prediction of yield, productivity, concentrations of yeast cells, sugars and ethanol.

Siqueira et al. (2008) obtained yields of $45.4 \%\left(\mathrm{Y}_{\mathrm{p} / \mathrm{s}}\right)$ and $45.8 \%$ $\left(\mathrm{Y}_{1}\right)$ at laboratory scale using agitation, similar to this study. Romão et al. (2012) studied the alcoholic fermentation of acid hydrolyzed soybean molasses and obtained yields of $60 \%\left(\mathrm{Y}_{1}\right)$ and $78 \%\left(\mathrm{Y}_{2}\right)$ at optimum conditions of hydrolysis. Silva et al. (2012) obtained yields of 67.5\% $\left(\mathrm{Y}_{1}\right)$ and $80.8\left(\mathrm{Y}_{2}\right)$ in optimum conditions of enzymatic hydrolysis and fermentation. The higher values of $Y_{1}$ in Romão et al. (2012) and Silva et al. (2012) studies is due the hydrolysis of non-fermentable to fermentable sugars, increasing the ethanol production and total sugar consumption.

The kinetic parameters were determinate from inclination of linear regression of experimental and mathematical data at the same range. Table 5 shows the kinetic parameters and time of cell generation. The experimental cell production ( $\mathrm{rx}$ ) was $0.046 \log$ cells $\mathrm{mL}^{-1} \mathrm{~h}^{-1}$, while theoretical determined from model was $0.037 \log$ cells $\mathrm{mL}^{-1} \mathrm{~h}^{-1}$, this value is $80.5 \%$ of the experimental data, which is considered a good estimative for a biological process.

The theoretical total sugars rate (rs) was $3.559 \mathrm{~g} \mathrm{~L}^{-1} \mathrm{~h}^{-1}$, very similar to the practical rate $\left(3.960 \mathrm{~g} \mathrm{~L}^{-1} \mathrm{~h}^{-1}\right)$. The rate of ethanol production was $1.701 \mathrm{~g} \mathrm{~L}^{-1} \mathrm{~h}^{-1}$ and $2.367 \mathrm{~g} \mathrm{~L}^{-1} \mathrm{~h}^{-1}$ determined from experimental and theoretical data, respectively. The predicted value represents $72 \%$ of the practical. The specific growth rate $(\mu \mathrm{x})$ and time of cell generation were $0.006 \mathrm{~h}^{-1}$ and $6.850 \mathrm{~h}$ for experimental data and $0.005 \mathrm{~h}^{-1}$ and $7.908 \mathrm{~h}$ for data determined by mathematical model, respectively.

Siqueira et al. (2008) reported the maximum ethanol productivity of $8.08 \mathrm{~g} \mathrm{~L}^{-1} \mathrm{~h}^{-1}$ conducing alcoholic fermentation of soybean molasses under agitation and initial cell concentration of $10^{8}$ cells $\mathrm{mL}^{-1}$ of $S$. cerevisiae. The low productivity and long cell generation time were expected due the low initial population $\left(10^{7}\right.$ cells $\left.\mathrm{mL}^{-1}\right)$ and absence of agitation, because of this, the yeast cells remain decanted, lowering the contact area between cells and substrate (sugars). Other factor that affects the yeast development is the high concentration of sugars in the media ( $30^{\circ}$ Brix), which promotes high osmotic pressure in the cells, delaying its growth (Ochoa-Estopier et al., 2011). The low specific cell production rate $(\mu \mathrm{x})$ can be explained by the low rs value in relation of high yeast population at the end of exponential phase of growth. A low $\mu \mathrm{x}$ of S. cerevisiae $\left(0.0189 \mathrm{~h}^{-1}\right)$ in soybean molasses fermentation was also founded by Siqueira et al. (2008).

\subsection{Mass balance}

Based in ethanol produced in this work, was determined the mass balance, and carbonic gas was estimated by stoichiometry (Equation 14) of ethanol production, where, for each $100 \mathrm{~kg}$ of ethanol, $96.65 \mathrm{~kg}$ of carbonic gas is also produced. This way, $1000 \mathrm{~kg}$ of soybean molasses can produce $103 \mathrm{~kg}$ of bioethanol and $98 \mathrm{~kg}$ of carbonic gas (Figure 2).

$$
\mathrm{C}_{6} \mathrm{H}_{12} \mathrm{O}_{6_{(\text {(Gluoses })}} \rightarrow 2 \mathrm{C}_{2} \mathrm{H}_{5} \mathrm{OH}_{(\text {Ethanol })}+2 \mathrm{CO}_{2 \text { (Carbonic gas) }}
$$

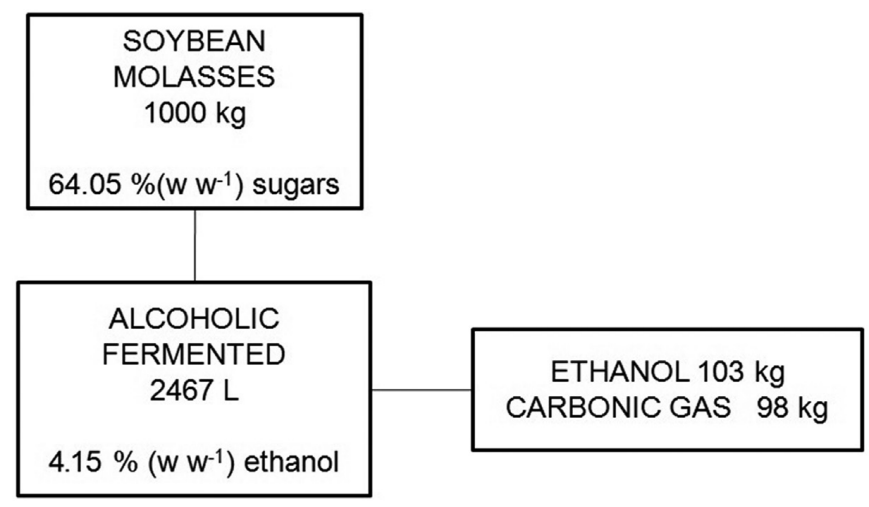

Figure 2. Mass balance from soybean molasses to ethanol.

Table 4. Fermentation yield and productivity for 44 hours of fermentation*.

\begin{tabular}{lccccccc}
\hline & $\begin{array}{c}\text { Time } \\
(\mathbf{h})\end{array}$ & $\begin{array}{c}\text { dTS } \\
\left(\mathbf{g ~ L}^{-1}\right)\end{array}$ & $\begin{array}{c}\text { dEt } \\
\left(\mathrm{g} \mathrm{L} \mathrm{L}^{-1}\right)\end{array}$ & $\begin{array}{c}\mathbf{Y}_{\mathrm{p} / \mathrm{s}} \\
(\%)\end{array}$ & $\begin{array}{c}\mathbf{Y}_{1} \\
(\%)\end{array}$ & $\begin{array}{c}\mathbf{Y}_{2} \\
(\%)\end{array}$ & $\begin{array}{c}\text { Productivity } \\
\left(\mathbf{g ~ L}^{-1} \mathbf{h}^{-1}\right)\end{array}$ \\
\hline Experimental data & 44 & 92.49 & 41.63 & 45.01 & 47.87 & 88.08 & 0.946 \\
Mathematical model & 44 & 97.49 & 41.08 & 42.14 & 46.12 & 82.46 \\
\hline
\end{tabular}

*dTS, total consumed sugars; $\mathrm{dEt}$, produced ethanol; $\mathrm{Y}_{\mathrm{p} / \mathrm{s}}$,yield from sugar; $\mathrm{Y}_{1}$, yield over total initial sugars, $\mathrm{Y}_{2}$, yield over consumed sugars.

Table 5. Fermentation kinetic parameters determined by using experimental data and mathematical model*.

\begin{tabular}{lccccc}
\hline & $\begin{array}{c}\mathbf{r x} \\
\left(\log \text { cells } \mathbf{~ L L}^{-1} \mathbf{h}^{-1}\right)\end{array}$ & $\begin{array}{c}\mathbf{r s} \\
\left(\mathrm{g} \mathrm{L}^{-1} \mathbf{h}^{-1}\right)\end{array}$ & $\begin{array}{c}\mathbf{r p} \\
\left(\mathrm{g} \mathrm{L}^{-1} \mathbf{h}^{-1}\right)\end{array}$ & $\begin{array}{c}\mu \mathrm{rx} \\
\left(\mathbf{h}^{-1}\right)\end{array}$ & $\begin{array}{c}\text { tg } \\
(\mathbf{h})\end{array}$ \\
\hline Experimental data & 0.046 & 3.960 & 2.367 & 0.006 & 6.850 \\
Mathematical model & 0.037 & 3.559 & 1.701 & 0.005 & 7.908 \\
\hline
\end{tabular}

${ }^{*}$ rx, cells production rate; rs, sugar consumption rate; rp, ethanol production rate; $\mu x$, specific growth rate; tg, cells generation time. 


\section{Conclusion}

Increasing soybean molasses concentration presented a positive effect in ethanol production and, despite the high concentration of soluble solids in the fermentative process ( $30^{\circ} \mathrm{Brix}$ ), the yeast had a good growing, which favored the yield and production of ethanol from soybean molasses.

The proposed mathematical models showed similar date to practical, mainly, yield and productivity parameters, then, the models can be used for bioethanol production at industrial scale.

Static fermentation is a cheap and simple process so the soybean molasses showed a potential raw material to production of bioethanol.

\section{Acknowledgements}

The authors thank the State University of Londrina and CAPES for financial support.

\section{References}

Association of Official Analytical Chemists - AOAC. (2005). Official methods of analysis of the Association Official Analytical Chemist (18th ed.). Arlington: AOAC.

Balat, M., Balat, H., \& Oz, C. (2008). Progress in bioethanol processing. Progress in Energy and Combustion Science, 34(5), 551-573. http:// dx.doi.org/10.1016/j.pecs.2007.11.001.

Behera, S., Kar, S., Mohanty, R. C., \& Ray, R. C. (2010). Comparative study of bioethanol production from mahula (Madhuca latifolia L.) flowers by Saccharomyces cerevisiae cells immobilized in agar agar and Caalginate matrices. Applied Energy, 87(1), 96-100. http:// dx.doi.org/10.1016/j.apenergy.2009.05.030.

Bligh, R. G., \& Dyer, W. J. (1959). A rapid method of total lipid extraction and purification. Canadian Journal of Biochemistry and Physiology, 37(8), 911-917. http://dx.doi.org/10.1139/o59-099. PMid:13671378.

Cardona, C. A., \& Sánchez, O. J. (2007). Fuel ethanol production: process design trends and integration opportunities. Bioresource Technology, 98(12), 2415-2457. http://dx.doi.org/10.1016/j.biortech.2007.01.002. PMid:17336061.

DuBois, M., Gilles, K. A., Hamilton, J. K., Rebers, P. A., \& Smith, F. (1956). Colorimetric method for determination of sugars and related substances. Analytical Chemistry, 28(3), 350-356. http://dx.doi. org/10.1021/ac60111a017.

Gámez, S., Cabriales, J. J. G., Ramírez, J. A., Garrote, G., \& Vázquez, M. (2005). Study of the hydrolysis of sugar cane bagasse using phosphoric acid. Journal of Food Engineering, 74(1), 78-88. http:// dx.doi.org/10.1016/j.jfoodeng.2005.02.005.

Hosny, M., \& Rosazza, J. P. N. (1999). Novel isoflavone, cinnamic acid ahd trterpenoid glycosides in soybean molasses. Journal of Natural Products, 62(6), 853-858. http://dx.doi.org/10.1021/np980566p. PMid:10395502.

Lan, Y., Williams, B. A., Verstegen, M. W. A., Patterson, R., \& Tamminga, S. (2007). Soy oligosaccharides in vitro fermentation characteristics and its effect on caecal microorganisms of young broiler chickens. Animal Feed Science Technology, 133(3-4), 286-297.

Machado, R. P. (1999). School of chemical engineering (Master's thesis). Universidade Federal do Rio Grande do Sul, Porto Alegre.

Miller, F., Caldeirão, L., Dorta, C., \& Marinelli, P. S. (2012). Obtenção de açúcares fermentescíveis a partir da casca de laranja e bagaço de cana-de-açúcar. Revista Analytica, 10, 50.

Nahvi, I., Emtiazi, G., \& Alkabi, L. (2002). Isolation of a flocculating Saccharomyces cerevisiae and investigation of its performance in the fermentation of beet molasses to ethanol. Biomass and Bioenergy, 23(6), 481-486. http://dx.doi.org/10.1016/S0961-9534(02)00070-3.

Nikolic, S., Mojovic, L., Pejin, D., Rakin, M., \& Vukasinovi, M. (2010). Production of bioethanol from corn meal hydrolyzates by free and immobilized cells of Saccharomyces cerevisiae var. ellipsoideus. Biomass and Bioenergy, 34(10), 1449-1456. http://dx.doi.org/10.1016/j. biombioe.2010.04.008.

Ochoa-Estopier, A., Lesaje, J., Gorret, N., \& Guilouet, S. E. (2011). Kinetic analysis of Saccharomyces cerevisiae stain adapted for improved growth on glicerol: Implacation of development of yeast bioprocess on glicerol. Bioresource Technology, 102(2), 1521-1527. http://dx.doi.org/10.1016/j.biortech.2010.08.003. PMid:20869237.

Oda, O., \& Nakamura, K. (2009). Production of ethanol from the mixture of beet molasses and cheese whey by a 2-deoxylucose-resistant mutant of Klyveromyces marxianus. FEMS Yeast Research, 9, 472478. http://10.1111/j.1567-1364.2009.00519.x. PMid: 19456875.

Romão, B. B., Silva, F. B., Resende, M. M., \& Cardoso, V. L. (2012). Ethanol production from hydrolyzed soybean molasses. Energy \& Fuels, 26(4), 2310-2316. http://dx.doi.org/10.1021/ef201908j.

Sage, R. F., Coiner, H. A., Way, D. A., Brett Runion, G., Prior, S. A., Allen Torbert, H., Sicher, R., \& Ziska, L. (2009). Kudzu. [Pueraria montana (Lour.) Merr. Variety lobata]: a new source of carbohydrate for bioethanol production. Biomass and Bioenergy, 33(1), 57-61. http://dx.doi.org/10.1016/j.biombioe.2008.04.011.

Silva, F. B., Romão, B. B., Cardoso, V. L., Coutinho, U. Fo., \& Ribeiro, E. J. (2012). Production of ethanol from enzymatically hydrolyzed soybean molasses. Biochemical Engineering Journal, 69, 61-68. http:// dx.doi.org/10.1016/j.bej.2012.08.009.

Siqueira, P. F., Krap, S. G., Carvalho, J. C., Sturm, W., Rodriguez-Leon, J. A., Tholozan, J. L., et al (2008). Production of bioethanol from soybean molasses by Saccharomyces cerevisiae at laboratory, pilot and industrial scales. Bioresource Technology, 99(17), 8156-8163. http://dx.doi.org/10.1016/j.biortech.2008.03.037. PMid:18485696.

Spinosa, W. A., \& Santos, V. Jr., Galvan, D., Fiorio, J. L., \& Gomez, R. J. H. C. (2015). Gomez. Vinegar rice (Oryza sativa L.) produced by a submerged fermentation process from alcoholic fermented rice. Food Science and Technology, 35(1), 196-201. http://dx.doi. org/10.1590/1678-457X.6605.

Srichuwong, S., Fujiwara, M., Wang, X., Seyama, T., Shiroma, R., Arakane, M., Mukojima, N., \& Tokuyasu, K. (2009). Simultaneous saccharification and fermentation (SSF) of very high gravity (VHG) potato mash for the production of ethanol. Biomass and Bioenergy, 33(5), 890-898. http://dx.doi.org/10.1016/j.biombioe.2009.01.012.

Statsoft. (2004). Statistica: data analysis software system. Version 7.0. Tulsa: Statsoft. Retrieved from www.statsoft.com 